\title{
IAMJ
}

INTERNATIONAL

AYURVEDIC

MEDICAL JOURNAL

Review Article

ISSN: $2320-5091$

Impact Factor: 6.719

\section{A CRITICAL REVIEW ON HRIDAYARNAVA RASA - AN HERBOMINERAL FORMULATION}

\author{
Pavithra G' ${ }^{1}$, Laxmi. B. Kurle ${ }^{2}$, Ravi. R. Chavan ${ }^{3}$ \\ ${ }^{1}$ Second Year PG Scholar, ${ }^{2}$ Associate Professor, ${ }^{3}$ Professor \&HOD \\ Department of Rasashastra and Bhaishajya Kalpana, T.G.A.M.C\&H, Ballari, Karnataka, India
}

Corresponding Author: pavitra5195@gmail.com

https://doi.org/10.46607/iamj4509092021

(Published Online: September 2021)

Open Access

(C) International Ayurvedic Medical Journal, India 2021

Article Received: 29/08//2021 - Peer Reviewed: 06/2021 - Accepted for Publication: 07/09/2021

\section{Check for updates}

\begin{abstract}
Hridroga is a broad entity considered in Ayurveda, covering all cardiovascular diseases. According to current studies, 17.5 million people die each year from cardiovascular diseases, with an estimated 31 per cent of death worldwide. Among them 7.4 million died due to coronary heart disease,6.7 million due to stroke, atherosclerosis etc., hence it is needed to discover effective drugs which can prevent death due to cardiovascular diseases and other cardiac disorders. Methods: Statins and fibrates are the most prescribed medications for cardiac disorders. Though there is extensive evidence about their safety and efficacy, but the use of these synthetic drugs has certain adverse effects; Myalgia, hepatopathy, renal failure, increased risk of diabetes and rhabdomyolysis are the most common side effects from statin use. Considering the wide magnitude of cardiac disorders in the Indian subcontinent and the absence of promising therapy with safety in conventional systems; the suffering population is turning towards certain other alternatives for safe and effective remedies. Hridayarnava rasa, one such Herbo- mineral compound formulation containing Kajjali and Tamra bhasma as an integral component indicated in the treatment of abnormal lipid levels. Results: Hridayarnava rasa is thereby useful in tackling Hridroga in specific, Atherosclerosis. Therefore, this formulation can be enforced in place of statins of conventional medicine. Discussion: This review is mainly focused on different aspects of Herbo mineral ayurvedic formulation Hridayarnava rasa. It is well recognized in Ayurveda that most cardiac disorders run a chronic course and are difficult to treat, there are many formulations in the market for Hridroga yet there is scope for drugs in this disease, Hridayarnava rasa is one such
\end{abstract}


formulation that is designed perfectly for kaphaja Hridroga, which is also cost-effective, easy to prepare, as it is hidden all these days its efficacy was not discussed so here an attempt has been made to address the critical review of Hridayarnava rasa.

Keywords: Hridayarnava rasa, Cardiovascular diseases, Hridroga.

\section{INTRODUCTION}

Nowadays, life has become so stressful, that the fast \& stressed lifestyle leads to many serious diseases such as Diabetes, Cardiovascular diseases, Hypertension, Stroke etc., cardiovascular diseases are the leading cause of death globally, hence there is a need to explore formulations that will help to prevent cardiac ailments. Hridroga is a disease of the heart either due to structural or functional damage. Because of the causative factors like athi ushna, guru, kashaya, tikta rasa Ati sevana, atishrama, abhighata, adhyashana. atiprasanga, vegadharana. adhika Chinta causes tridosha prakopa, reaches Hridaya and does dushana of hrudayagata rasa and causes ama utpatti further causes avarodha of srotas (atherosclerosis, coronary artery disease, plaques), Atipravutti of vata (fibrillation, vessel enlargement, palpitations) hence produces the disease Hridroga. Ayurveda being the ancient science of life provides various formulations which can take care of cardiovascular diseases without any complications. Hridayarnava rasa is one such formulation described in most of the Rasashastra texts and widely used in practice for the prevention and cure of $\mathrm{Hri}$ droga.

The main objective of this review article is to discuss the therapeutic uses of Hridayarnava Rasa and to discuss the different pharmacological properties and therapeutic uses of isolated constituent drugs of Hridayarnava Rasa. The authentic subject material has been reviewed from Ayurveda and modern medical literature. Different research and review articles were searched in different journals. This review is mainly focused on different aspects of Herbo mineral Ayurvedic formulation Hridayarnava Rasa.

Various Rasashastra texts have depicted Hridayarnava rasa, the most widely used formulation taken from the text Rasendra Sara Sangraha in Hridroga chikitsa, detailed review of the same is undertaken in the present study. Other references are quoted from Rasakamadhenu, Rasachandamshu etc. having similar ingredients but different drug designs in relation with parts of Tamra in the formulation.

MATERIALS AND METHODS:

\section{INGREDIENTS:}

Table 1: Showing the Ingredients of Hridayarnava Rasa in various texts

\begin{tabular}{|l|l|l|l|l|}
\hline References & Parada & Gandhaka & Tamra bhasma & Bhavana Dravya \\
\hline Rasendra Sara Sangraha & 1 part & 1 part & 2 parts & Triphala Kwatha \& Kakamachi swarasa \\
\hline Rasa chandamsu & 1 part & 1 part & 2 parts & Triphala Kwatha \& Kakamachi swarasa \\
\hline Rasatarangini & 1 part & 1 part & 2 parts & Triphala Kwatha \& Kakamachi swarasa \\
\hline Rasendra Chintamani & 1 part & 1 part & 1 part & Triphala Kwatha \& Kakamachi swarasa \\
\hline Yogaratnakara & 1 part & 1 part & 1 part & Triphala Kwatha \& Kakamachi swarasa \\
\hline Rasakamadhenu & 1 part & 1 part & 1 part & Triphala Kwatha \& Kakamachi swarasa \\
\hline Bhaisajyaratnavali & 1 part & 1 part & 1 part & Triphala Kwatha \& Kakamachi swarasa \\
\hline
\end{tabular}

\section{METHOD OF PREPARATION:}

- Kajjali is prepared by adding equal parts of Shuddha parada and Shuddha Gandhaka in a clean khalwa yantra.
- After proper Mardana of Kajjali, 2 parts of Tamra bhasma is added and Mardana samskara is carried out until it becomes a homogeneous mixture

- Then it is subjected to Bhavana with Triphala Kwatha and Kakamachi swarasa one day each, 
followed by preparing vatis of chana Matra pramana, later it is dried in shade.

DOSAGE: 125 to $250 \mathrm{mg}$

ANUPANA: Kakamachi phala-1 Karsha

Triphala-1 Pala

Jala-32 tola
Above mentioned quantity is taken and Kwatha is prepared by

Reducing it to $1 / 8$ th is used as Anupana.

There is a difference of opinion regarding Anupana for Hridayarnava rasa by various authors, which is mentioned as follows.

Table 2: Showing the Difference of opinion regarding Anupana, of Hridayarnava rasa in various texts

\begin{tabular}{|l|l|l|l|}
\hline References & Dose & Indications & Anupana \\
\hline Rasendra Sara Sangraha & Chana Matra & Kaphaja Hridroga & Kwatha prepared out of Triphala and Kakamachi \\
\hline Rasa chandamsu & Chana Matra & Kaphaja Hridroga & Kwatha prepared out of Triphala and Kakamachi \\
\hline Rasatarangini & Raktikapaada & Hridroga & Not mentioned \\
\hline Rasendra Chintamani & Chana Matra & Hridroga & Madhu and Tambula Patra swarasa \\
\hline Yogaratnakara & Chana Matra & Hridroga & Not mentioned \\
\hline Rasakamadhenu & Chana Matra & Hridroga & Madhu and Arjuna Kwatha \\
\hline Bhaisajyaratnavali & Chana Matra & Hridroga & Arjunadi Kwatha \\
\hline
\end{tabular}

Table 3: Showing the properties of individual drugs of Hridayarnava rasa

\begin{tabular}{|c|c|c|c|c|c|}
\hline DRUG & $\boldsymbol{R A S A}$ & GUNA & VEERYA & VIPAKA & DOSHAGHNATA \\
\hline Parada $^{3}$ & Shadrasa & $\begin{array}{l}\text { Snigdha, Sara and } \\
\text { Guru }\end{array}$ & Ushna & Madhura & Tridoshaghna \\
\hline Gandhaka & $\begin{array}{l}\text { Madhura }{ }^{4}, \quad \text { Katu, } \\
\text { Tikta, Kashaya }\end{array}$ & Ushna, Sara, Snigdha. & Ushna & Katu & $\begin{array}{l}\text { Kapha Vatahara, Pitta- } \\
\text { vardhaka. }\end{array}$ \\
\hline $\begin{array}{l}\text { Tamra } \\
\text { bhasma }\end{array}$ & $\begin{array}{l}\text { Tikta, } \quad \text { Kashaya, } \\
\text { Madhura, } \text { Amla }^{6,7}\end{array}$ & Laghu, Sara ${ }^{7}$ & $\begin{array}{l}\text { Ushna }^{6,8} \\
\text { Sheeta }^{7}\end{array}$ & $\begin{array}{l}\text { Madhura }^{6,8} \\
\text { Katu }^{7}\end{array}$ & Pitta-Kaphara ${ }^{6,7,8}$ \\
\hline Haritaki $^{9}$ & $\begin{array}{ll}\text { Kashaya, } & \text { Tikta, } \\
\text { Madhura, } & \text { Katu, } \\
\text { Amla } & \end{array}$ & Laghu, Ruksha & Ushna & Madhura & $\begin{array}{l}\text { Tridosha Shamaka, } \\
\text { Vatashamaka }\end{array}$ \\
\hline Vibhitaki $^{10}$ & Kashaya & Ruksha, Laghu & Ushna & Madhura & $\begin{array}{l}\text { Kaphahara, Tridosha } \\
\text { Shamaka }\end{array}$ \\
\hline Amalaki ${ }^{11}$ & $\begin{array}{lr}\text { Amla, } & \text { Madhura, } \\
\text { Kashay, } & \text { Tikta, } \\
\text { Katu } & \end{array}$ & Guru, Ruksha, Sheeta & Sheeta & Madhura & $\begin{array}{l}\text { Pittashamak, Tridosha } \\
\text { Shamaka }\end{array}$ \\
\hline Kakamachi $^{12}$ & Tikta & Laghu, Snigdha & Anushna & Katu & Tridosha Shamaka \\
\hline
\end{tabular}

\begin{tabular}{|c|c|c|}
\hline DRUG & $K A R M A$ & ROGAGHNATA \\
\hline Parada & $\begin{array}{l}\text { Yogavahi, rasayana, Vrishya, Balya, vayastam- } \\
\text { bana, pustikaraka, deepana, agnivardhaka, deha } \\
\text { and Loha siddikara, ropana, krimighna. }\end{array}$ & $\begin{array}{l}\text { Vata roga, vali palita, jara, sarva akshi roga, krimi, } \\
\text { kusta. }\end{array}$ \\
\hline Gandhaka & Deepana, Pachana, Vishahara, Jantughna & $\begin{array}{l}\text { Kandu, Visarpa, Krimi, Kustha, Kshaya, Pleeha, Ra- } \\
\text { sayana. }\end{array}$ \\
\hline $\begin{array}{l}\text { Tamra } \\
\text { bhasma }\end{array}$ & $\begin{array}{l}\text { Netrya, Lekhana, Urdhwa-adha parishodana } \\
\text { Kshutkarma }{ }^{6} \text {,Saraka, Ropana }\end{array}$ & $\begin{array}{l}\text { Udara roga, Kusta, Sthoulya, Pandu, } 6 \text {, Garavisha, } \\
\text { Swasa, Kasa, Kshaya, Pinasa, Shula, Amlapitta, } \\
\text { Krimi }^{7}, \text { Arsha, Grahani } \\
\text {, Apasmara, Yakritvikara }\end{array}$ \\
\hline
\end{tabular}




\begin{tabular}{|c|c|c|}
\hline Haritaki & $\begin{array}{l}\text { Anulomana, Mridurechana, Grahi, Vrishya, Hri- } \\
\text { dya, Shonithasthapana, Rasayana, Medhya, } \\
\text { Chakshushya }\end{array}$ & $\begin{array}{l}\text { Vatavyadhi, Vrana, Rakatavikara, Vatarakta, Shwasa, } \\
\text { Prameha, Swarabheda }\end{array}$ \\
\hline Vibhitaki & $\begin{array}{l}\text { shotahara, vedanasthapana, rakta stambana, } \\
\text { deepana, vajikarana, jwaragna } \\
\text { anulomana, bhedhana, rechana, krimighna }\end{array}$ & $\begin{array}{l}\text { Shotha-Vedanayuktavikara, Hridhya, Charmaroga, } \\
\text { Granthi, Visapa, } \\
\text { Agnimandhya, }\end{array}$ \\
\hline Amalaki & $\begin{array}{l}\text { Dahaprashamana, Chakhushya, Keshya, Medhya, } \\
\text { Balya, Rechna, Deepana, Hridya, } \\
\text { Anulomana, Rasayana, Pramehagna, Jwaraghna }\end{array}$ & $\begin{array}{l}\text { Mastishkadourbalya, Drishtimandya, } \\
\text { Indriyadourbalya, Dourbalya, Vibandha, Kasa, } \\
\text { Shwasa, Rakatapitta. }\end{array}$ \\
\hline Kakamachi & $\begin{array}{l}\text { Shotahara, Vranashodana, Raktashodana, } \\
\text { Vishaghna, Chakshushya, Rasayana, Shwasahara, } \\
\text { Jwaraghna, Hridya }\end{array}$ & $\begin{array}{l}\text { Shotha, Urustamba, Vrana, Visarapa, Udara, } \\
\text { Yakritshotha, Arsha, } \\
\text { Pravahika, Atisara, Amavata }\end{array}$ \\
\hline
\end{tabular}

ANAL YTICAL FINDINGS:

Organoleptic characters

Colour-black

Smell - faint

Touch - fine

Taste-tasteless

\section{Quantitative estimation}

- Free sulphur-- not more than $17.81 \%$

- Combined sulphur-- not more than $5.95 \%$ not less than $4.05 \%$

- Mercury-- not more than 25.3 not less than 22.3

- Copper as $\mathrm{CuO}$ not more than 2.53 not less than 24.6

- Calcium as $\mathrm{Ca}$ - not more than 1.33 not less than 1.24

- Iron as Fe203 -not more than 14.37

- Phosphate as Po4 not more than 1.0

- Sodium as Na - not more than 1.0

- Ash value-- not more than 58.17 not less than 51.04

- Acid insoluble ash- not more than 6.1 not less than 2.9

- Volatile matter - not more than 3.73 not less than 1.97

\section{DISCUSSION}

The formulation that has been selected in the present study for review is first described by Rasendra Sara Sangraha. The same formula was adopted by $R a$ sachandamsu, Rasatarangini, Rasendra Chintamani, Yogaratnakara,

Rasakamadhenu,
Bhaishajyaratnavali. In Rasendra Sara sangraha Rasachandamsu \& Rasatarangini the quantity of Tamra bhasma is 2 parts rest of the authors mentioned 1 part of Tamra bhasma. There is also difference of opinion regarding anupana for Hridayarnava rasa, In Rasendra Sara sangraha and Rasa chandamsu, Kwatha prepared out of Triphala and Kakamachi was mentioned as anupana, In Rasendra Chintamani it is administered along with Madhu and Tambulapatra swarasa, in Rasakamadhenu it is administered with Madhu and Arjuna Kwatha, in Bhaishajyaratnavali it is along with Arjunadi Kwatha, in Rasatarangini and Yogaratnakara no specific anupana is mentioned.

By reviewing the ingredients of the formulation, it is found that most of the drugs having Madhura, Tikta, Kashaya rasa, Laghu, Ruksha, Ushna Guna, Ushna veerya, Madhura vipaka so they neutralize the kupitha Kapha dosha, almost all the drugs having Hridya property hence Hridayarnava rasa is indicated in Kaphaja Hridroga.

- Kajjali owns properties like Rasayana, Yogavahi, sarvarogahara, these properties of kajjali are essential to enhance efficacy and potency in the prepared medicine, when mixed with other medicines they become more potent and act in low doses. Kajjali increases the bioavailability of the drug, which helps to obtain greater efficiency of the drug, it gives strength to the cardiac muscles by its Rasayana property, it subsides the hridayashritha Vayu dusti.

- Tamra bhasma is reported as Medhopaha, Lekhana and Sthoulyahara and it is helpful in 
Hypercholesteremia and Dyslipidemia. Tamra bhasma has madhura rasa, katu \& madhura vipaka, sheeta virya, laghuguna, pittahara and kapha hara properties. Due to lekhana and karshana properties, it removes atherosclerosis and platelet aggravation, rejuvenates the damaged tissue of heart muscles, it acts as a tonic to heartlung apparatus. Tamra bhasma being a scraping agent it reduces untoward unusual or damaged parts; it clears micro- channel openings of the coronary arteries. Due to scraping properties, it reduces thrombolytic atherosclerotic changes. Tamra bhasma increases absorption of iron and acts on the liver and cures cardiorespiratory ailments.

Tamra bhasma possess a rich source of copper, copper is one of the vital trace elements of the body required for normal physiological functions, copper deficiency leads to hypercholesterolemia leads to CVD, copper plays a special role in lipid metabolism. Diet rich in copper has a beneficial effect on blood cholesterol.

- $\quad$ Triphala is having shodhana, rasayana properties. Haritaki plays an important role in blood circulation and cleansing of macro and microcirculatory channels, it is having hypolipidemic and Hypocholesterolemic properties. Vibhitaki aids in purification and circulation of blood in the body, fruit extract of Terminalia bellerica shows hepatoprotective activity, it facilitates in controlling fat metabolism and blood cholesterol level, it aids in treatment of liver by reducing atherosclerosis. Amalaki regulates the liver and accelerates blood clotting, it is rich in vitamin $\mathrm{c}$ and acts as a powerful antioxidant agent by removing excess free radicals. Regular intake of Amalaki shows an increase in cardiac glycogen and decrease in serum GOT, GPT, and LDH which suggests a cardioprotective action. Triphala exerts a marked cardioprotective effect, reduces serum cholesterol, improves circulation, reduces high blood pressure helps in the management of cardiac disorders.

- Kakamachi swarasa is having Bhedana, Hridya, Kaphahara, Pittahara, Rasayana, Vatahara, properties, the cardioprotective activity of methanolic extract of berries of the plant Solanum nigrum was evaluated by using global in vitro ischemia-reperfusion injury carried out using doses of 2.5 and $5.0 \mathrm{mg} / \mathrm{kg}$ for 6 days for 30 days. The results indicate that the extract exhibited significant $(\mathrm{p}<0.001)$ cardioprotective activity against the global in-vitro ischemia-reperfusion activity.

- Arjuna is an excellent cardiotonic and cardioprotector. It is potent in strengthening the cardiac muscles, improving the circulation of the coronary arteries and prevents cardiac muscles from ischemic damage. Arjuna kwatha as anupana for hridayarnava rasa by virtue of all the above properties thus helps to fortify the organ, prevents accumulation of plaque thereby beneficial in $\mathrm{Hri}$ droga.

- By considering specific actions of Prabhakar $V a t i$, we can make out that it will work better in CVD's which require strength to the myocardium like Left ventricular hypertrophy and right ventricular hypertrophy, where we need more Rasayana properties. But in the case of IHD more we need to concentrate on the removal of blockages which may be because of atheroma, Hridayarnava rasa will work better by removing blockages and by preventing further accumulation.

\section{CONCLUSION}

This review has presented a collective knowledge on therapeutic, pharmacological, and medicinal applications of Hridayarnava rasa and its constituent drugs. Cardio protectivity is classified as a physiological approach of cardio protectivity and a therapeutic approach of cardio protectivity. The same concept was explained in our texts thousands of years ago i.e., Hridya (physiological) and Hridrogahara (Therapeutic) Dravya. Amalaki, Haritaki, Kakamachi are having Hridya property and Tamra bhasma is having Hridroga hara property and kajjali as Yogavahi exerts best action in hridayagata Vikaras. Hridayarnava rasa is a best rasoushadhi indicated in kaphaja Hridroga. Quantity of Tamra bhasma is 2 parts acc to RSS, $R$ Cha, RT. The rest of the authors mentions 1 
part, Kakamachi, Haritaki Amalaki and Tamra bhasma are proved as cardioprotective. The anupana varies according to different authors. Hridayarnava rasa is safe for therapeutic use at its normal dose.

\section{REFERENCES}

1. Bhaishajya Ratnavali, Govindas, Hridroga Chikitsa Prakarana, Ambikadatta shastri, Chaukhamba prakashan (U.P) edition,2016;692.

2. Acharya Agnivesha, Charaka Samhita, Ayurveda Deepika Commentary of Chakrapani, Edited by Vaidya Yadavji Trikamji Acharya, Chaukambha Krishnadas Academy, Varanasi Year of reprint:2019, Chikista Sthana, Chapter 26, vese-80, page no 637.

3. Vaidya Pandit Hariprapannaji, Rasa yoga Sagara, with Hindi Translation, Reprint, Varanasi, Krishnadas Academy,1998, Volume II,275pp.

4. Bhava Mishra, Bhava Prakash, Translated by Prof, K.R. Srikanth Murthy, English translation, $1^{\text {st }}$ edition Varanasi, Krishnadas Academy Publication,1998, Volume I, Chapter 6, Subchapter 7, verse,90-92,345pp.

5. Shri Vagbhatacharya, Rasa Ratna Samucchaya, Hindi translation Edited by Prof. Dattatreya Anata Kulkarni,

6. Reprint, New Delhi, Meharchand Lachhmandas publication,2006, $3^{\text {rd }}$ chapter,15 -16 verse.45pp.

7. Sri Vagbhatacharya, Rasa Ratna Samuchaya, Edited by Indradev Tripathi, ${ }^{\text {rd }}$ Edition, Varanasi, Chaukambha Sanskrit bhavan,2006, $5^{\text {th }}$ chapter, verse 46,57pp.

8. Acharya Sri Madhava, Ayurveda Prakash, Edited by Gulraj Sharma Mishra, $2^{\text {nd }}$ Edition(reprint), Varanasi, Chaukambha Bharat Academy,2007,3 ${ }^{\text {rd }}$ chapter, verse:145-146,373pp.

9. Sri Sadananda Sharma, Rasa Tarangini, Edited by Kashinatha Shastri, $11^{\text {th }}$ Edition, New Delhi, Motilala Banarsidas Publication, $1979,17^{\text {th }}$ Taranga, verse 49,420pp.

10. Dept of Ayush. CCRAS. Database on medicinal plants used in Ayurveda and siddha, prof G.S. Levekar et, al, New Delhi,2007, vol3,283pp

11. Dept of Ayush. CCRAS. Data base on medicinal plants used in Ayurveda and siddha, prof G.S. Levekar et, al, New Delhi,2007, vol3,159pp

12. Dept of Ayush. CCRAS. Data base on medicinal plants used in Ayurveda and siddha, prof G.S. Levekar et, al, New Delhi,2007, vol3,12pp

13. Dept of Ayush. CCRAS. Data base on medicinal plants used in Ayurveda and Siddha, prof G.S. Levekar et, al, New Delhi,2007, vol3,348pp

\section{Source of Support: Nil Conflict of Interest: None Declared}

How to cite this URL: Pavitra G et al: A Critical Review On Hridayarnava Rasa - An Herbomineral Formulation. International Ayurvedic Medical Journal \{online\} 2021 \{cited September 2021\} Available from: http://www.iamj.in/posts/images/upload/2213_2218.pdf 